local self-government bodies three different types of electoral system are used; 4) elections to local self-government bodies are carried out in the respective territorial single-mandate and multi-mandate constituencies; 5) ramified system of territorial election commissions that have their own special status, the order of formation, composition and powers; 6) a large number of ballot papers during the voting, which slows down the work of the polling station election commissions during the issuance of ballot papers, the direct expression of the will of the voters, the counting of ballot papers and the establishment of the final election result; 7) in the elections to local self-government bodies, the active participation of electoral rights is limited to the greatest extent compared to parliamentary and presidential elections in Ukraine; 8) in the elections to local self-government bodies, the smallest turnout of voters is observed compared to parliamentary and presidential elections in Ukraine, which is steadily decreasing from one local election to another.

Key words: elections, electoral law, electoral process, electoral system, local selfgovernment bodies, Ukraine.

DOI https://doi.org/10.33766/2524-0323.86.68-78

УДК 349.2 (477)

Л. В. Перевалова,

кандидат філософських наук, доцент, завідувач кафедри права Національного технічного університету «Харківський політехнічни інститут» (м. Харків, Україна) e-mail: perevalovaluda@ukr.net, iD https:// orcid.org/0000-0001-5182-2838

I. В. Лисенко, кандидат юридичних наук, доцент, доцент кафедри права Національного технічного університету «Харківський політехнічний інститут» (м. Харків, Україна) e-mail: irina8119@ukr.net iD https://orcid.org/0000-0003-3392-6056

А. М. Лисенко, кандидат юридичних наук, доцент, доцент кафедри оперативно - розшукової діяльності Харківського національного університету внутрішніх справ (м. Харків, Україна)

e-mail: lan11.07.1979@gmail.com, (iD https:/ / orcid.org/0000-0003-0780-2148

\title{
ПРОБЛЕМИ ПРАЦЕВЛАШТУВАННЯ МОЛОДІ НА СУЧАСНОМУ ЕТАПІ РОЗВИТКУ УКРАЇНСЬКОГО СУСПІЛЬСТВА
}

Стаття присвячена проблемам молоді на ринку праці в Україні, серед яких: безробіття, низький рівень життя, небажання роботодавців оформлювати легальні трудові відносини, зростання міграційних процесів, пов'язаних із (C) Перевалова Л. В., Лисенко І. В., Лисенко А. М., 2019 
працевлаштуванням за кордоном. Автори розглядають причини виникнення зазначених проблем. У статті надана характеристика порушень, які найчастіше зустрічаються в цій сфері, аналізуються їх наслідки для молодих людей, які працюють із порушення діючого законодавства про працю. Наведені статистичні данні про стан молоді на ринку праці в Україні дозволяють авторам зробити логічні висновки та надати пропозиції щодо покращення становища молоді.

Ключові слова: нелегальна зайнятість, неформальні трудові відносини, безробіття, трудовий договір, випробувальний час, стажування, мінімальна заробітна плата.

Постановка проблеми. Молодь України перебуває сьогодні в центрі усіх політичних, соціальних, економічних подій, які відбуваються в країні. Завдяки своєму високому творчому потенціалу, мобільності та гнучкості молоді люди впливають на всі суспільні відносини, від них залежить майбутнє нашої держави та і всього світу в цілому. Кризові явища в країні в першу чергу впливають на стан молоді, яка $\epsilon$ найбільш незахищеною соціальною групою. Серед основних проблем, 3 якими стикається молодь, треба виокремити низькій рівень матеріального забезпечення, що безпосередньо пов'язане 3 проблемами працевлаштуванням, пошуками роботи, рівнем прибутку.

Євроінтеграційний курс нашої країни потребує адаптації українського законодавства до стандартів Європейського Союзу. Однак українські реалії в сфері трудових відносин характеризуються двояким характером. 3 однієї сторони декларується європейський вектор розвитку в сфері трудового законодавства, а з іншого - існуюча практика показує, що регулювання трудових відносин не тільки не наближується, а навпаки розходиться 3 європейськими стандартами. Головна проблема сучасної України - не в необхідності прийняття нового законодавства, а в його виконанні.

Аналіз останніх досліджень і публікацій. Проблемам сучасної молоді присвячені наукові праці багатьох українських учених. Так Д. Мельничук [1], О. Натолока приділяють увагу стану зайнятості, працевлаштуванню молоді [2], а дослідники Є. Головаха, О. Позняк, Л. Мерлян розглядають питання трудові орієнтації молоді $[3,4,5]$; міграційні процеси, що існують у молодіжному середовищі, знайшли відображення в працях В. Чорної, Г. Щерби $[6,7]$.

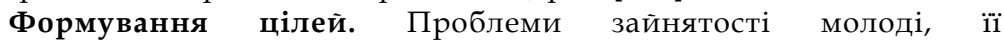
працевлаштування в умовах кризових явищ у країні є недостатньо вивченими, що викликає необхідність подальшого дослідження цих процесів та запропонування шляхів виходу з цієї ситуації.

Виклад основного матеріалу. Сучасний стан ринку праці свідчить, що значний трудовий потенціал молоді використовується не в повному обсязі. Це пов'язано з наявністю таких причин, як гостра конкурентна боротьба на ринку праці, зниження трудової активності молоді, скорочення робочих місць, зростання безробіття, нелегальна 
зайнятість, міграційні процеси в цілому. Особливо від такої ситуації страждає молодь. Слід погодитися з точкою зору багатьох науковців, що в основі цих негативних тенденцій лежить недосконалість механізмів державного регулювання молодіжного сегменту ринку [8].

Згідно із Законом України «Про сприяння соціальному становленню та розвитку молоді» молоддю вважають громадян віком від 14 до 35 років [9]. Сьогодні молодій особі, яка щойно закінчила навчання та має намір розпочати свою трудову діяльність, досить складно знайти роботу, яка б відповідала основним їі вимогам (рід занять, пов'язаний з отриманими професією чи навичками, достойна оплата праці). Результати соціологічного дослідження «Молодь України - 2017», яке проводилось Центром незалежних соціологічних досліджень «ОМЕГА» на замовлення Міністерства молоді та спорту України, показали, що майже половина опитаної молоді $(48,1$ \%), яка працевлаштована, працює не за фахом чи спеціальністю, отриманою в професійно-технічному або вищому навчальному закладі. Головними чинниками, які пояснюють, чому молодь не працює за здобутим фахом, є відсутність відповідних вакансій (36,7\%) та незадовільна матеріальна винагорода (31,4 \%) [10, с. 45].

Основними причинами виникнення труднощів при працевлаштуванні молоді, як правил, називають відсутність трудового стажу, недостатній рівень практичних навичок, висока конкуренція на ринку праці в конкретній професії, велика кількість пропозицій на ринку праці, відсутність попиту на отриману професію. Усе це призводить до зростання безробіття серед української молоді.

За даними Державної служби зайнятості загальна чисельність безробітних у 2017 році складала 1,4 млн. осіб, з них 0,3 млн.- шукали роботу вперше та не мали відповідного досвіду. До останньої категорії в основному належала молодь, яка була не працевлаштована після закінчення навчальних закладів. Зокрема, серед таких безробітних у 2017 р. частка осіб віком 15-24 роки складала 77,7 \%, а у віці 25-29 років - 20,7 \%. Серед молоді у віці від 15 до 34 років 54,8 \% були зайняті в різних сферах економіки, 12,3 \% - безробітні, 3 яких 18,9 \% - це молоді особи у віці 15-24 роки, 11,3 \% - 25-29 років, 9,8 \% складали молоді люди віком 30-34 роки [11].

Протягом січня-вересня 2018 року статус безробітного мали 303,0 тис. осіб з числа молоді (36 \% від загальної кількості безробітних). За віковими групами: серед безробітних 29 \% становили особи віком від 15 до 29 років і 31 \% - особи у віці від 30 до 39 років. Однак, можна впевнено стверджувати, що значна кількість молоді не зверталася до служби зайнятості, і сьогодні багато молодих людей працюють без оформлення трудових відносин [12].

Ще однією причиною погіршення стану молоді на ринку праці є порушення трудового законодавства роботодавцями при прийнятті 
на роботу. Одним із таких порушень є так звані дискримінаційні вимоги роботодавця до кандидата на посаду. Це обмеження, пов'язані 3 віком, статтю чи зовнішністю претендента. Відповідно до статті 2 ${ }^{1}$ Кодексу законів про працю (далі КЗПП) забороняється будь-яка дискримінація в сфері праці, зокрема порушення принципу рівності прав і можливостей, пряме або непряме обмеження прав працівників залежно від раси, кольору шкіри, політичних, релігійних та інших переконань, статі, гендерної ідентичності, сексуальної орієнтації, етнічного, соціального та іноземного походження, віку, стану здоров'я, інвалідності, підозри чи наявності захворювання на ВІЛ/СНІД, сімейного та майнового стану, сімейних обов'язків, місця проживання, членства в професійній спілці чи іншому об'єднанні громадян, участі в страйку, звернення або наміру звернення до суду чи інших органів за захистом своїх прав або надання підтримки іншим працівникам у захисті їх прав, за також за мовними або іншими ознаками, не пов'язаними 3 характером роботи або умовами ії виконання [13].

Другим поширеним порушенням є вимога документів, не передбачених чинним законодавством. За загальними правилами, особа, що влаштовується на роботу, має подати заяву про укладення трудового договору, документ, що посвідчує особу (для більшості громадян це паспорт), трудову книжку (крім осіб, що вперше укладають трудовий договір), документ про освіту (якщо робота вимагає певної кваліфікації). Усі інші документи слід надавати тільки тоді, коли їх прямо передбачає законодавство з огляду на специфіку праці. Проте працівники часто стверджують, що 3 них при працевлаштуванні вимагали характеристики, рекомендації 3 попереднього місця роботи, медичний огляд (медичні книжки), а також просили заповнити анкети, які містять питання явно дискримінаційного характеру (зокрема про політичні й інші переконання).

Крім того, гострою проблемою, 3 якою зіткнулася Україна, є розповсюдження трудових відносин без офіційного оформлення. Найбільш актуально це для молоді, яка не має досвіду роботи. Після завершення навчання випускники мають труднощі із пошуком роботи через брак досвіду. На жаль, лише незначна кількість роботодавців погоджується взяти на роботу працівника без нього. Таким чином, молоді люди опиняються в ситуаціях, коли наявність будь-якої роботи сприймається як велике благо, навіть якщо це робота не за фахом і не відповідає особистим бажанням. Молоді люди йдуть працювати в кафе, бари, ресторани, у сферу торгівлі, на будівництво, тобто туди й на ту роботу, яка не потребує спеціальних знань. Наслідками даного явища $є$ те, що впродовж перших 3-5 років молодь часто змінює робочі місця. Серед основних причин, звісно, і пошук свого покликання, але найчастіше - незадовільні умови праці. 
Якщо роботодавець і приймає молоду особу на роботу, то він може запропонувати пройти випробувальний термін без оформлення трудових відносин. Причому працівнику пропонується попрацювати безкоштовно чи за плату, значно меншу, ніж для інших працівників (зрозуміло, що йдеться про оплату «в конверті», виплата якої залежить винятково від сумління роботодавця). Сама по собі така позиція роботодавця $є$ протиправною, оскільки прийняття на роботу 3 випробуванням означає укладення трудового договору, і з моменту початку роботи починає нараховуватися страховий стаж, а працівник отримує всі належні трудові права, включно з правом на повноцінну оплату праці. Сдиною суттєвою відмінністю є те, що працівника може бути звільнено як такого, що не пройшов випробування, але це не скасовує ні стажу, ні оплати праці за період випробування.

Інше порушення стосується терміну випробування. КЗпП України (ст. 27) встановлює, що строк випробування при прийнятті на роботу, якщо інше не встановлено законодавством України, не може перевищувати трьох місяців, а в окремих випадках, за погодженням 3 відповідним виборним органом первинної профспілкової організації, - шести місяців, причому строк випробування при прийнятті на роботу робітників не може перевищувати одного місяця [13].

Найчастіші молоді люди скаржаться на те, що роботодавець пропонує їм пройти стажування. Їх цікавіть питання, чим відрізняється випробувальний термін від стажування. Зауважимо, що стажування проводиться до початку прийому на роботу, а випробування - у процесі роботи. Трудове законодавство визначає стажування як навчання на виробництві. Згідно із законодавством, стажування може бути запропоновано лише особам, які претендують на зайняття певної посади й потребують практичного досвіду, закріплення теоретичних знань на практиці. Але роботодавці пропонують стажування будь-яким категоріям працівників, незалежно від освіти, досвіду роботи та на будь-який термін. Молодій особі, яка наймається на роботу, слід пам'ятати, що стажування - це навчання, а отже, воно може бути платним і безоплатним, може оплачуватися як за рахунок підприємства-роботодавця, так і за рахунок працівника. Практика свідчить, що таке стажування здійснюється на безоплатній основі, тобто працівник під час стажування не одержує заробітної плати. Роботодавці пояснюють це тим, що вони навчають майбутнього працівника, витрачають час найбільш кваліфікованих працівників, і, як наслідок, несуть збитки. Наслідком такого «стажування», швидше за все, буде відмова в прийнятті на роботу із залучанням на вакантне місце наступного стажера.

Праця без оформлення трудових відносин - це грубе порушення діючого трудового законодавства. Молода особа, яка погоджується працювати без укладання трудового договору й згодна одержувати 
заробітну платню в конверті, опиняється вкрай у невигідному становищі. Наслідками такої згоди $є$ наступне: працівник позбавляється гарантованого розміру заробітної плати (у тому числі розміру тарифної ставки або посадового окладу працівника, доплати, надбавки); він втрачає можливості користування державними гарантіями відповідно до чинного законодавства, як-от: державна допомога сім'ям 3 дітьми, соціальна допомога малозабезпеченим сім'ям, субсидії; втрачає трудовий стаж при розрахунку розміру пенсії; при відсутності внесків до фондів соціального страхування, $\mathrm{i}$ як наслідок, соціального захисту, втрачає право на отримання гарантованої державою відпустки, а також своєчасні мінімальні гарантії в оплаті праці та безпечні умови роботи.

До того ж негативні наслідки від такої праці відчувають органи місцевого самоврядування i держава в цілому. Не оформлені належним чином трудові відносини призводять до наступного: ненадходження податків до місцевих бюджетів, які б направлялися на добробут громади, на реалізацію програм соціально-економічного розвитку районів, міст; нестабільності та невпевненості в майбутньому громадян (відсутність належного розміру пенсій, інших соціальних виплат); не наповнення фондів соціального страхування й надмірного навантаження на них.

Молоді люди, які працюють нелегально, без оформлення трудових відносин, як правило, пояснюють свій вибір тим, що їм потрібно допомогти батькам, оплатити навчання, квартиру тощо. Однак, заробітна платня, яку вони одержують, не відповідає встановленим нормам, частіше є меншою, ніж було запропоновано під час співбесіди або в об'яві; оплата праці нестабільна і залежить від продаж або виробленої продукції. У будь якому разі середня заробітна плата (досить низька чи мінімальна) не відповідає прожитковому рівню й не дозволяє молодій особі відчувати себе впевнено. У пошуках гідних умов праці молоді люди дуже часто змінюють місце проживання, місце роботи; вони продовжують залежати від допомоги батьків, не мають нормального житла, а коли йдеться про плани на майбутнє, говорять лише про наступний місяць, не заглядаючи наперед, адже планувати на довшу перспективу неможливо через описані вище причини.

За результатами соціологічного дослідження «Молодь України 2017» 74,1 \% молодих людей хотіли б виїхати зі свого населеного пункту за межі України. Найбільше бажаючих серед української молоді переїхати зі свого населеного пункту до країн Свропейського Союзу $(45,6$ \%), до інших країн світу $(21,7$ \%) та до країн СНД $(6,8$ \%). До іншої місцевості в Україні виявила бажання переїхати кожна п'ята молода людина $(21,7 \%)$, яка б хотіла змінити місце проживання. Головною причиною еміграції молоді 3 України є бажання підвищити матеріальний добробут або заробити гроші (54,1 \% від тих, хто хотів би емігрувати з України), що є наслідком складної економічної ситуації в 
країні. Серед інших причин можливої еміграції респонденти називають відсутність можливостей в Україні, порівняно 3 іншими країнами, відсутність у державі реальної демократії та законності, а також бажання працевлаштуватися за кордоном [10, с. 33, 39].

Висновки. Досвід розвинутих країн світу свідчить, що подолати безробіття, нелегальну зайнятість, міграцію молоді можливо тільки шляхом формування такого положення, коли як працівники, так i роботодавці будуть зацікавлені здійснювати трудові відносини у відповідності до законодавства. Реалізувати це можливо завдяки встановленню переваг у сфері сплати податків, соціальних внесків, стандартів безпеки, розвитку економічної інфраструктури, сприяння підприємництву, впровадженню програм стимулювання й підтримки бізнесу, встановлення стабільних правил регулювання соціальнотрудової сфери. Держава повинна залучати до здійснення молодіжної політики молодіжні організації, державну службу зайнятості, органи місцевого самоврядування, засоби масової інформації, навчальні заклади 3 метою забезпечення підготовки молоді до трудової діяльності, підтримувати молодіжні ініціативи, спрямовані на підготовку, працевлаштування та кар'єрне зростання молоді. Зробити це можливо тільки маючи повну та всебічну інформацію про становище молоді на ринку праці. Молоді люди повинні розуміти, яку важливу роль вони відіграють та будуть відігравати в майбутньому в розвитку своєї країни.

\section{Використані джерела:}

1. Богоявленська Ю. В., Мельничук Д. П. Зайнятість молоді в Україні : стан, актуальні завдання та пріоритетні кроки. URL : http:/ / ela.kpi.ua/bitstream/123456789/ 6387/3/82-87.pdf (дата звернення 02.07.2019).

2. Натолока О. О. Основні проблеми працевлаштування молоді в Україні. URL : http://www.kbuapa.kharkov.ua/e-book/conf/2013-2/doc/2/22.pdf (дата звернення 02.07.2019).

3. Головаха Є. Ставлення до влади і політичний вибір молоді України. Соціологія: теорія, методи, маркетинг : науково-теоретичний часопис. 2002. № 1. С.117-127.

4. Мерлян Л. Молодежная занятость - резервы рынка труда в Украине? Менеджер по персоналу. 2008. № 5. С. 56-60.

5. Позняк О. Внешние трудовые миграции в Украине. Менеджер по персоналу. 2008. № 10. C. 16- 20.

6. Чорна В. О. Трудова міграція молоді як фактор руйнування трудового потенщіалу України. UR L: http://www.npchdusoc_2014_234_222_24.pdf (дата звернення 03.07.2019).

7. Щерба Г. І. Трудова міграція молоді та її наслідки для дітей в українському суспільстві. URL : http://www.usoc_2011_3_15.pdf (дата звернення 10.07.2019).

8. Високос А. I, Клименюк Н. В. Проблеми працевлаштування випускників вищих навчальних закладів. URL: http:/ / www.90217-189364-1-SM.pdf (дата звернення 10.07.2019). 
9. Про сприяння соціальному становленню та розвитку молоді: Закон України редакція від 1 січня 2017 р., № 1774-VIII. URL : http:/ / zakon.rada.gov.ua/ laws/show/2998-12 (дата звернення 10.07.2019).

10. Молодь України - 2017 : результати соціологічного дослідження. Тернопіль : ТОВ «Терно-граф», 2017. 72 с.

11. Економічна активність населення України 2017 : статистичний збірник. Київ : Державна служба статистики України, 2018. 203 с. URL: http://www.ukrstat.gov.ua/ druk/publicat/kat_u/2018/zb/07/zb_EAN_2017.pdf (дата звернення 10.07.2019).

12. Надання послуг особам з числа молоді. Державна служба зайнятості. Аналітичні та статистичні данні. URL: http://www.dcz.gov.ua/analitics/68 (дата звернення 10.07.2019).

13. Кодекс законів про працю України : станом на 11 жовт. 2018 р. № 2542VIII. URL: http:/ / zakon.rada.gov.ua/laws/show/322-08 (дата звернення 10.07.2019).

\section{References:}

1. Yu. V. Bohoiavlenska, Melnychuk D. P. Zainiatist molodi v Ukraini : stan, aktualni zavdannia ta priorytetni kroky[Youth Employment in Ukraine: Status, Topical Tasks and Priority Steps]. URL: http://ela.kpi.ua/bitstream/123456789/6387/3/8287.pdf (data zvernennya 02.07.2019) (in Ukr.)

2. Natoloka O. O. Osnovni problemy pratsevlashtuvannia molodi v Ukraini [The main problems of youth employment in Ukraine]. URL: http://www.kbuapa.kharkov.ua/ ebook/conf/2013-2/doc/2/22.pdf (data zvernennya 02.07.2019) (in Ukr.)

3. Holovakha Ye. Stavlennia do vlady i politychnyi vybir molodi Ukrainy [Attitude to power and political choice of young people of Ukraine]. Sotsiolohiia : teoriia, metody, marketynh : Naukovo-teoretychnyi chasopys. 2002. №1. S. 117-127 (in Ukr.).

4. Merlian L. Molodezhnaia zaniatost - rezervu runka truda v Ukrayne? [Youth employment - labor market reserves in Ukraine?] Menedzher po personalu. 2008. № 5. S. 56-60 (in Russ.).

5. Pozniak O. Vneshnye trudovue myhratsyy v Ukrayne [External labor migrations in Ukraine]. Menedzher po personalu. 2008. № 10. S. 16-20 (in Russ.).

6. Chorna V. O. Trudova mihratsiia molodi yak faktor ruinuvannia trudovoho potentsialu Ukrainy [Labor Migration of Young People, Yak, Factor of Ruinizing Labor Potential of Ukraine]. URL: file http://www.npchdusoc_2014_234_222_24.pdf (data zvernennya 03.07.2019) (in Ukr.).

7. Shcherba H. I. Trudova mihratsiia molodi ta yii naslidky dlia ditei $v$ ukrainskomu suspilstvi [Labor Migration of Youth and Its Implications for Children in Ukrainian Society]. URL: http://www.usoc_2011_3_15.pdf (data zvernennya 10.07.2019) (in Ukr.).

8. Vysokos A. I., Klymeniuk N. V., Problemy pratsevlashtuvannia vypusknykiv vyshchykh navchalnykh zakladiv [Problems of Employment of Graduates of Higher Educational Institutions]. URL: http:/ / www.90217-189364-1-SM.pdf (data zvernennya 10.07.2019) (in Ukr.).

9. Pro spryiannia sotsialnomu stanovlenniu ta rozvytku molodi : Zakon Ukrainy [On promoting social development and youth development : Law of Ukraine] redaktsiia vid 01.01.2017, № 1774-VIII. URL: http://zakon.rada.gov.ua/laws/ show/2998-12 (data zvernennya 10.07.2019) (in Ukr.).

10. Molod Ukrainy - 2017 : rezultaty sotsiolohichnoho doslidzhennia [Youth of Ukraine - 2017 : results of sociological research]. Ternopil : TOV «Terno-hraf», 2017. 72 s. (in Ukr.). 
11. Ekonomichna aktyvnist naselennia Ukrainy. 2017 : statystychnyi zbirnyk [Economic activity of the population of Ukraine. 2017. Statistical collection.]. Kyiv : Derzhavna sluzhba statystyky Ukrainy. 2018. 203 s. URL: http://www.ukrstat.gov.ua/ druk/publicat/kat_u/2018/zb/07/zb_EAN_2017.pdf (data zvernennya 10.07.2019) (in Ukr.).

12. Nadannia posluh osobam $z$ chysla molodi. Derzhavna sluzhba zainiatosti. Analitychni ta statystychni danni. [Providing services to young people. State Employment Service. Analytical and statistical data.]. URL: https:/ / www.dcz.gov.ua/ analitics / 68 (data zvernennya 10.07.2019) (in Ukr.).

13. Kodeks zakoniv pro pratsiu Ukrainy [ Labor Code of Ukraine] : stanom na 11.10.2018. № 2542-VIII. URL:http://zakon.rada.gov.ua/laws/show/322-08 (data zvernennya 10.07.2019) (in Ukr.)

Стаття надіӥшла до редколегії 06.05.2019

Перевалова Л. В., кандидат философских наук, доцент, заведующий кафедры права

Национального технического университета «Харьковский политехнический институт» (г. Харьков, Украина) Лисенко И. В. кандидат юридичних наук, доцент, доцент кафедры права Национального технического университета «Харьковский политехнический институт»

(г. Харьков, Украина) Лисенко А. М., кандидат юридических наук, доцент, доцент кафедры оперативно-розыскной деятельности Харьковского национального университета внутренних дел (г. Харьков, Украина)

\section{ПРОБЛЕМЫ ТРУДОУСТРОЙСТВА МОЛОДЕЖИ НА СОВРЕМЕННОМ ЭТАПЕ РАЗВИТИЯ УКРАИНСКОГО ОБЩЕСТВА}

Статья посвящена проблемам молодежи на рынке труда в Украине, к которым относятся: безработица, низкий уровень жизни, нежелание работодателей оформлять легальные трудовые отношения, рост миграционных процессов, связанных с трудоустройством зарубежом. Авторы рассматривают причины возникновения указанных проблем. В статье дается характеристика нарушений, которые наиболее часто встречаются в этой сфере, анализируются их последствия для молодых людей, которые работают с нарушением действующего законодательства о труде. Приведенные статистические данные о состоянии молодежи на рынке труда в Украине, позволяют авторам сделать логические выводы и предложения по улучшению положения молодежи.

Ключевые слова: нелегальная занятость, неформальные трудовые отношения, безработица, трудовой договор, испытательный срок, стажировка, минимальная заработная плата. 
Perevalova L.

$\mathrm{Ph}$. D. in philosophical sciences, associate professor, head of the department of law

National technical university «Kharkiv polytechnic institute»

(Kharkiv, Ukraine)

Lysenko I.

Ph. D. in law, associate professor, associate professor of the department of law National technical university «Kharkiv polytechnic institute»

(Kharkiv, Ukraine)

Lysenko A.

Ph. D. in law, associate professor, associate professor of the department of operative-investigative activityand crime detection Kharkiv National university of internal affairs (Kharkiv, Ukraine)

\section{PROBLEMS OF YOUTH EMPLOYMENT AT THE PRESENT STAGE OF DEVELOPMENT OF UKRAINIAN SOCIETY}

The article is devoted to the problems of Ukrainian youth, which under the condition of crisis is in an extremely disadvantageous position. Among the main problems faced by young people, the authors point out a low level of material support, which is directly related to difficulties while searching for a job, applying for vacancies, and the income level of a young person. Attention is paid to the fact that in the field of labor relations in the country, on the one hand, the European integration course is declared, and on the other hand, the existing practice shows that the regulation of labor relations not only does not approach to European standards, but on the contrary disagrees with them. On the basis of sociological studies, statistical data, the authors study the reasons of unemployment growth in Ukraine: lack of work in the specialty, low salary, unsatisfactory conditions of work. Lack of work experience, lack of practical skills, and high competition on the labor market lead to difficulties in employing for young people. The authors analyze such reasons of the worsening of the situation of young people on the labor market as violations of labor legislation by the employer while hiring: discriminatory restrictions on age, sex, appearance, marital status, property status, the requirement of documents which are not provided for by the legislation, increasing of probation periods, the replacement of probation with an internship. The most acute problem faced by young people is illegal employment. The employee is hired without official employment procedure, and it leads to the fact that a person loses the guaranteed amount of wages, paid vacation, state guarantees, her/she does not pay social insurance and a pension fund contributions. All this leads to the fact that young people for a long time depend on the material support of their parents, they do not have their own housing, family, children. All this leads increasing of migration processes. Most young people are focused on leaving Ukraine to the countries of the European Union. The main reason for emigration is the desire for improving their financial status, the lack of decent job, real democracy and the rule of 
law in Ukraine. Analysis of sociological and statistical data allows the authors to make logical conclusions and suggestions for improving the status of young people.

Key words: illegal employment, informal labor relations, unemployment, employment contract, trial period, training, minimum wage.

\title{
DOI
}

УДК 342.4

\author{
В. Л. Федоренко, \\ доктор юридичних наук, професор, \\ директор Науково-дослідного центру судової \\ експертизи з питань інтелектуальної власності \\ Міністерства юстиції України, заслужений юрист \\ України, судовий експерт вищого кваліфікаційного класу \\ (м. Київ, Україна) \\ e-mail: fedorenko900@gmail.com \\ (iD https://orcid.org/0000-0001-5902-1226
}

\section{КОНСТИТУЦІЯ ТА КОНСТИТУЦІОНЛІЗМ: СУТНІСТЬ, СЕНСИ І ВЗАЄМОЗУМОВЛЕНІСТЬ}

Публікація покликана дослідити походження та поняття категорії «конституція», iї взаємозв'язкам із категорією «конституціоналізм» у сучасних демократичних правових державах. Аналізуються витоки українських конституцій і конституційних актів від Конституції Пилипа Орлика 1710 р. до чинної Конституції України 1996 р. Узагальнюються та систематизуються найбільш поширені підходи до визначення сутності конституцій і їх сенсу для розвитку суспільства та держави, як-от: позитивістський, природно-правовий, соціологічний, політологічний, інституційний, синтетичний тощо.

Ключові слова: конституція; основний закон; Конституція України; Конституція Пилипа Орлика; конституціоналізм; конституціоналізація.

Постановка проблеми. Як відомо, конституції стали найважливішим здобутком національної політико-правової думки, втілили найкращі здобутки державотворення та розбудови громадянського суспільства, а в ряді держав світу також нормативно закріпили перемоги в революціях, війнах за незалежність тощо. Недаремно для понад 40 країн світу, включно з Україною, день прийняття конституції став найважливішим загальнонаціональним святом.

День конституції є важливим загальнонаціональним святом для норвежців, поляків, словаків, японщів. У США це свято було офіційно визнано лише понад 10 років тому, хоча за фактом американці відзначають цей день упродовж майже півстоліття. До того ж, у багатьох державах світу конституції та дата їх прийняття нерідко втілюються в матеріальних об'єктах культури. Так у столиці Іспанії місті Мадриді зведено монумент у формі порожнистого кубу як найбілыш досконалої геометричної фігури з надписом: «Народ Мадриду - Конституції 1978 року». Іншим прикладом є пагорб Конституції в місті Йоганесбургу (ПАР). Поряд зі спорудою в' язнищі, де свого часу утримувалися жертви апартеїду та політичних репресій, було зведено офіційну резиденцію Конституційного Суду цієї (С) Федоренко В. Л., 2019 